\title{
UNIKÁLIS INNOVÁCIÓ ÉS GAZDASÁGI SOKK
}

Selmeczi-Kovács Zsolt - Kuttor Dániel - Németh Gábor - Pál Zsolt ${ }^{1}$

A 2020 márciusában és azt követően tapasztalt változások kétségtelenül jelentős hatással voltak a magyar gazdaságra. A hónap elején a magyar pénzforgalom meghatározó mérföldkövéhez érkeztünk, március 2-án elindult az azonnali fizetési szolgáltatás. Ez szinte napra pontosan megegyezett a Covid-19 járvány magyarországi megjelenésével (az első regisztrált esetet március 4-én jelentették be). Az azonnali fizetési rendszer bevezetésétől a piaci szereplők előzetesen az átutalások számának növekedését, a készpénz használatának visszaszorulását, a gazdaság élénkülését várták, míg a vírushelyzet nyomán bevezetett korlátozó intézkedések vélhetően az üzleti élet legtöbb területét negatívan befolyásolták.

Jelen tanulmányban azt kívánjuk vizsgálni, hogy ezen ellentétes irányú hatások hogyan mutatkoztak meg a Bankközi Klíring Rendszer adataiban a 2020. március elejétől június végéig terjedő időszakban.

JEL-kódok: $\mathrm{E}_{42}, \mathrm{~N}_{24}, \mathrm{O}_{30}$

Kulcsszavak: elszámolásforgalom, bankközi klíring, elszámolóház, azonnali átutalás, digitalizáció, innováció, fintech, Covid-19, koronavírus, pandémia

\section{A HAZAI ELSZÁMOLÁSI ÉS KIEGYENLÍTÉSI INFRASTRUKTÚRA}

Magyarországon alapvetően három fő elszámolási/kiegyenlítési rendszer müködik:

I. A valós idejű bruttó elszámolási rendszert (VIBER) az MNB működteti. Ez a rendszer a nagyösszegü, időkritikus fizetések elszámolását és kiegyenlítését szolgálja.

II. A KELER és KELER KSZF által üzemeltetett rendszerek az azonnali és határidős értékpapír-, energia- és árupiacügyletek elszámolását végzik.

III. A GIRO Zrt. által müködtetett Bankközi Klíring Rendszer (BKR) a hitelintézetek közötti nagy tömegü, kis egyedi összegü fizetési megbízások (átutalások és beszedések) lebonyolítását szolgálja.

1 Selmeczi-Kovács Zsolt vezérigazgató, GIRO Zrt. E-mail: selmeczikovacs.zsolt@mail.giro.hu. Kuttor Dániel egyetemi docens, Miskolci Egyetem. E-mail: kuttor.daniel@uni-miskolc.hu. Németh Gábor főosztályvezető, GIRO Zrt. E-mail: nemeth.gabor@mail.giro.hu. Pál Zsolt egyetemi docens, Miskolci Egyetem. E-mail: pal.zsolt@uni-miskolc.hu. 
Mindezek mellett elsősorban a postai fizetések elszámolását végző Posta Elszámoló Központ (PEK), a bankkártyaműveletek elszámolását végző nemzetközi kártyatársaságok által müködtetett rendszerek és a Magyar Nemzeti Bank által működtetett CLS nemzetközi devizaforgalmi rendszer említhető meg (Kovács et al., 2016; MNB, 2020).

\subsection{A Bankközi Klíring Rendszer}

Az átutalások és beszedések forgalmának túlnyomó része belföldi gazdasági tevékenységekhez kötődik. A nemzetközi fizetési forgalom az elmúlt években folyamatosan növekedett. Ennek ellenére az országhatáron átnyúló tranzakciók még a hazánkhoz hasonlóan kis és nyitott gazdaságok esetében sem haladják meg a fizetés forgalom 2-3 százalékát.

Magyarországon a belföldi bankközi tranzakciók elszámolását a GIRO Zrt. által működtetett Bankközi Klíring Rendszer (BKR) végzi. Az elszámolás teljes mértékben elektronikus úton, emberi beavatkozás nélkül, a GIRO Zrt. által fenntartott, védett kommunikációs csatornán keresztül történik, ezzel járulva hozzá a stabilitáshoz és a bankrendszerbe vetett bizalom fenntartásához (Kovács, 2017).

A BKR három elszámolási módban működik:

- Az 1994 óta működő éjszakai elszámolási mód, az InterGIRO1 (IG1) platform minden, az MNB-nek a pénzforgalom lebonyolításáról szóló rendeletében meghatározott átutalás és beszedés fizetési mód elszámolását támogatja ( $D a ́$ vid-Kovács, 2019).

- A 2012. július 2-án bevezetett napközbeni elszámolásban (InterGIRO2, IG2) kizárólag átutalások elszámolására kerül sor. Kezdetben napi 5 (szombati munkanapokon 3) ciklusban müködött, 2015. szeptember 7-étöl napi 10 (szombati munkanapokon 7) ciklusban dolgozik.

- 2020. március 2-án kezdte meg müködését az azonnali fizetési rendszer (GIROInstant platform), amely a forintalapú, döntően a tízmillió forintot meg nem haladó, belföldi elektronikus átutalások néhány másodpercen belüli teljesülését teszi lehetővé az év minden napján, annak minden órájában (penzforgalom.hu).

\subsection{Az azonnali fizetési rendszer}

Az azonnali fizetés egy átutalás típusú fizetési mód. Lényege, hogy a legfeljebb 10 millió forintos, elektronikus úton indított, egyedi belföldi átutalások folyamatosan, néhány másodperc alatt teljesülnek. 
Kiegészítő szolgáltatásként az azonnali fizetési rendszer lehetővé teszi, hogy az átutalásokat a számlaszám ismerete nélkül, ún. másodlagos számlaazonosítók alkalmazásával (mobiltelefonszám, e-mail cím, adószám, adóazonosító jel) lehessen indítani. Egy másik kiegészítő szolgáltatás a fizetési kérelem, amely gyakorlatilag egy üzenet. Lehetővé teszi, hogy a kedvezményezett kezdeményezzen átutalási megbízást. Az átutalási megbízás a fizető fél jóváhagyásával jön létre. Szemléltetésként következzen egy eset: az eladó a vásárlás végösszegének megfelelő fizetési kérelmet küld vásárlójának üzenetként a telefonjára, a vevő a kérelem elfogadásával egy automatikusan generált, azonnali átutalási megbízást küld a számlavezető bankjának, így megtörténik a vásárlás ellenértékének pénzügyi teljesítése.

Az azonnali fizetés maga a „készpénz nélküli készpénz”, hiszen kényelmes és versenyképes alternatívája a készpénzes fizetésnek (GIRO Zrt., penzforgalom.hu).

Világviszonylatban is kiemelkedő, hogy a magyar bankszektorban - a GIRO Zrt. és a Magyar Nemzeti Bank eredményes együttmüködése nyomán - minden pénzforgalmi szolgáltatónál egyszerre vezették be az azonnali fizetési rendszert, míg más, hasonló rendszert használó országokban ez a szolgáltatás jellemzően csak a bankrendszer bizonyos részére terjed ki (MNB, 2020; Kovács, 2016).

\section{A COVID-19 PANDÉMIA MEGJELENÉSE ÉS MAGYARORSZÁGI HATÁSAI}

A SARS-CoV-2 vírus okozta tüdőgyulladás-járvány kitöréséről a kínai egészségügyi hatóságok 2019. december végén számoltak be hivatalosan az Egészségügyi Világszervezetnek (WHO). A fertőzést okozó, ún. új koronavírust Vuhan városában, Hupej tartomány székhelyén azonosították (WHO honlapja). Az elkövetkező hónapokban a betegség gyorsan terjedt Kínában, majd az egész világon.

Az Európai Unió területén 2020. január 24-én, Franciaországból jelentették az első fertőzöttet. Az Európai Betegségmegelőzési és Járványvédelmi Központ (ECDC) 2020. februári adatközlése alapján a betegség hivatalos neve „koronavírus-betegség 2019” (coronavirus disease 2019), rövidített elnevezése a Covid-19 lett (ECDC honlapja).

A járványt 2020. március 11-én az Egészségügyi Világszervezet (WHO) világjárvánnyá nyilvánította. Március közepén az új esetszámok alapján a WHO már Európát és nem Kínát tekintette a járvány aktív gócpontjának (Váradi et al., 2020). Az ezt követő időszakban a fertőzés megállíthatatlanul terjedt tovább az amerikai és afrikai kontinensekre is.

Magyarországon március 4-én jelentették az első SARS-CoV-2 vírussal összefüggésbe hozható fertőzést, illetve március 15-én az első elhunyt beteget. 
A pandémia nem csupán az egyes országok egészségügyi rendszerében okoz, okozott példátlan stresszt, hanem sokkolta a teljes gazdasági szférát. Ezt igazolták a 2020. évi első és második negyedéves GDP-adatok negatív számai is a világ minden régiójából. A nemzetközi közlekedés és szállítás blokkolása, majd leállása, ehhez kapcsolódóan a világkereskedelem és -turizmus „befagyása”, a termelési láncok megszakadása immáron globális méretü gazdasági válságot generált. A különböző kormányok, valamint nemzetközi szervezetek (WBG, IMF) és együttmüködések (EU, OECD) saját eszköztárukkal igyekeznek megállítani, illetve mérsékelni a gazdaság drasztikus visszaesését. Elsődleges feladattá vált a munkaerőpiaci helyzet (a tömegessé váló munkanélküliség) kezelése, valamint a lakossági fogyasztás, illetve a vállalati hitelezés (a likviditás) fenntartása (Baldwin et al., 2020).

Magyarország kormánya a pandémia időszakának elejétől igyekezett - lehetőségeihez mérten - beavatkozni, emellett a vészhelyzet idején (március 11-étől június 18-áig) a gazdaságot élénkítő intézkedéseket hozni.

Április hetedikén ismertették és vezették be az ún. új gazdaságvédelmi akcióterv elemeit, amelyek között az adminisztratív és fizetési vagy adóterhek csökkentését célzó beavatkozásokat is találni (kormany.hu) A legfontosabb elemek a következők:

- fizetési moratórium, a lakossági és vállalati kölcsönökre vonatkozó fizetési haladék;

- munkabér átvállalása az állam részéről (3 hónapig 70 százalékban) a munkák leállásának idejére;

- felgyorsított áfa-visszaigénylés és elhalasztott adóbevallás (vállalatok részére);

- szabad és ingyenes online képzések, a nyelvvizsga-kötelezettség eltörlése, kedvezményes diákhitel;

- az idegenforgalmi adó (IFA) felfüggesztése.

A járványhelyzet miatt az új hitelkihelyezések is jelentősen mérséklödtek, amit az állami (babaváró hitel) és a jegybanki (NHP Hajrá) programok csak enyhíteni tudtak. A vállalati hitelezésben az NHP Hajrá program elindítása, valamint a Magyar Fejlesztési Bank és az Eximbank kedvezményes hitelkonstrukciói ösztönzik a hitelezési aktivitást, a háztartási hitelezésben a családi otthonteremtési kedvezményhez (CSOK), valamint a babaváró konstrukcióhoz kapcsolódó hitelfelvételek fennmaradása adhat támaszt a hitelezésnek (MNB, 202ob).

A továbbiakban megállapításainkat, következtetéseinket elsősorban a Bankközi Klíring Rendszer információira alapozzuk, a hitelezés vizsgálatakor azonban az elszámolásforgalmi adatokon túl (pl. hiteltörlesztés jogcímű beszedések alakulása) kézenfekvő a Központi Hitelinformációs Rendszer (KHR) számaira is támasz- 
kodni. A KHR adataiból az látszik, hogy az új programoknak, illetve a megszorítások enyhítésének köszönhetően - az április-május havi rendkívül alacsony forgalom (10,0\%-os, illetve 17,1\%-os visszaesés) után - június hónapban már közel bázisszinten ${ }^{2}$ alakultak a hitelinformációs lekérdezések, ami a hitelezés élénkülésére utal. (KHR - GIRO/BISZ).

\section{NÉGY HÓNAP ELSZÁMOLÁSFORGALMA SZÁMOKBAN}

\subsection{Módszertani sajátosságok}

A pénzforgalmi adatok vizsgálata a gazdaság számos szegmensére vonatkozóan hatékony elemzési módszer. Az elektronikus tranzakciók mennyisége és értéke jól reprezentálja a mögöttes gazdasági eseményeket, így az egyes tranzakciótípusok adatai fontos gazdasági indikátorok lehetnek.

A statisztikai mutatószámok esetén az adatokat a szezonalitás kiszürése érdekében a bázisév azonos időszakához érdemes viszonyítani. A BKR esetében több ízben így is teszünk, az azonnali fizetés (GIROInstant platform) kapcsán mégis önmagában (havi összesen), vagy az előző hónaphoz viszonyítva történik a forgalom alakulásának vizsgálata. Ennek oka egyrészről az, hogy nem áll rendelkezésre adat az előző év azonos időszakáról, másrészről pedig egy új szolgáltatás elindításakor önmagában is érdekes, hogy hónapról hónapra hogyan fut fel a forgalom.

\subsection{A Bankközi Klíring Rendszer alakulása}

Tekintettel arra, hogy a BKR mind a magánszemélyek, mind a jogi személyek pénzforgalmának jelentős hányadát lefedi, forgalmának alakulása a gazdaság egészének teljesítményéről nyújt azonnali visszajelzést. A koronavírus okozta veszélyhelyzet számos iparágban eredményezett lassulást vagy leállást, ami az adófizetések, a munkabérek vagy éppen a hiteltörlesztések darabszámában is viszszatükröződik. A BKR március, április, május, június havi forgalmát vizsgálva megfigyelhetők a kormány járvány elleni és gazdaságvédelmi intézkedéseinek hatásai.

A Bankközi Klíring Rendszer egészét tekintve, a vizsgált időszak elején, 2020 márciusában még a forgalom rendkívül magas növekedési üteme $(6,3 \%)$ volt megfigyelhető, majd két szűkös „koronavírusos” hónap (-2,1\% és -6,4\%) következett,

2 Bázis: az előző év azonos hónapja (2019. június). 
amely után júniusban a BKR-forgalom az év második legmagasabb növekedését produkálta $(+4,1 \%)$.

1. táblázat

A Bankközi Klíring Rendszer átutalásainak havi száma és változása

\begin{tabular}{|c|c|c|c|c|c|c|c|c|}
\hline \multirow[t]{2}{*}{ Megnevezés } & \multicolumn{4}{|c|}{$\begin{array}{l}\text { Tranzakciószám - } \\
2020 \text { (ezer db) }\end{array}$} & \multicolumn{4}{|c|}{$\begin{array}{c}\text { Változás } 2019 \\
\text { azonos hónapjához képest (\%) }\end{array}$} \\
\hline & március & április & május & június & március & április & május & június \\
\hline Egyedi tételek & 19506 & 18014 & 17427 & 18061 & $10,3 \%$ & $2,0 \%$ & $-3,8 \%$ & $8,2 \%$ \\
\hline $\begin{array}{l}\text { Csoportos } \\
\text { beszedés }\end{array}$ & 6677 & 6065 & 6114 & 6186 & $1,8 \%$ & $-9,7 \%$ & $-9,6 \%$ & $-2,3 \%$ \\
\hline $\begin{array}{l}\text { Csoportos } \\
\text { átutalás }\end{array}$ & 6713 & 6842 & 6351 & 6699 & $1,7 \%$ & $-2,4 \%$ & $-7,8 \%$ & $2,1 \%$ \\
\hline PEK & 560 & 570 & 519 & 587 & $-1,0 \%$ & $-8,7 \%$ & $-10,1 \%$ & $-0,1 \%$ \\
\hline Visszautasítások & 355 & 231 & 235 & 247 & $-8,1 \%$ & $-41,5 \%$ & $-42,4 \%$ & $-31,5 \%$ \\
\hline BKR összesen & 33811 & 31723 & 30644 & 31780 & $6,3 \%$ & $-2,1 \%$ & $-6,4 \%$ & $4,1 \%$ \\
\hline
\end{tabular}

Forrás: GIRO Zrt.

\subsubsection{Egyedi tételek forgalma}

A márciusi összesített bankközi klíringforgalom alakulását elsősorban az egyedi tételek, ezen belül is az üzleti jellegű egyedi tételek kiugróan magas bővülése határozta meg. A növekedés hátterében döntő tényező lehet a két többletmunkanap, illetve a gazdasági növekedés. A márciusi forgalom nagy meglepetést okozott, mivel ekkor még semmi nem tükröződött a koronavírus következtében előálló gazdasági nehézségekből. Mivel jelentős gazdasági szektorok (pl. autógyártás, turizmus, vendéglátás, építőipar) kerültek egyik pillanatról a másikra szélsőségesen nehéz piaci körülmények közé, várható volt, hogy ennek - az üzleti egyedi tételek terén biztosan - előbb vagy utóbb meg kell mutatkoznia. Az adófizetési moratóriumnak hasonlóképpen komoly forgalomcsökkentő hatása volt prognosztizálható az adó jellegü egyedi tételekre nézve.

Az áprilisi forgalom összességében 2,1\%-kal csökkent az elöző év azonos időszakához képest, amihez hasonlóra a 2008-as válságot követő időben nem volt példa, így mindenképpen figyelmeztető erővel bírt. Ebben a hónapban az egyedi átutalások forgalma még növekedést mutatott (+2,0\%), de összetevői közül az Államkincstár felé címzett, jellemzően adó jellegü utalások forgalmában masszív visszaesés $(-9,1 \%)$ volt megfigyelhető. Ennek hátterében a veszélyeztetett ágazatba tartozó vállalkozások adó- és járulékfizetési könnyítései húzódnak meg. Az üzleti jellegü tételek 4,7\%-os növekedése még biztató jelként volt értékelhető, de hónapon belül a növekedés üteme csökkenő tendenciát mutatott. A kormányzati és kutatói előrejelzések ekkor egyaránt azt valószínüsítik, hogy a második negyedév 
gazdasági mutatói kedvezőtlenül alakulnak, a második félév teljesítménye pedig alapvetően függ attól, hogyan sikerül a gazdaság újraindítását, illetve a járvány elleni védekezést optimálisan összehangolni. Mindez természetesen közvetlen hatással bír a bankközi átutalási forgalomra is.

Amint az várható volt, májusban már jelentősebb mértékben, 6,4 százalékkal esett vissza a tranzakciószám. A koronavírus elleni hatékony védekezés miatt a gazdaság szinte minden ága harapófogóba került. A termelést a kereslet csökkenése kívülről, a foglalkoztatottság visszaesése, illetve a szállítói láncok beszakadása belülről fogta vissza. Az ipari termelés 36,8\%-kal, az export 7,3\%-kal, az import 5,5\%-kal esett vissza.

A forgalom csökkenése szerkezetében az áprilisitól csak annyiban tért el, hogy a gazdaság ilyen mértékű lefojtása már az egyedi tranzakciók forgalmában is csökkenést eredményezett. A forgalom ebben a hónapban már jelentősen visszaesett úgy, hogy nemcsak az adójellegü (-12,7\%), de már az üzleti tranzakciók forgalma is visszaesett $(-1,5 \%)$, jóllehet még mindig csak jóval csekélyebb mértékben.

A május végi elemzői becslések azt valószínűsítették, hogy a gazdaság túl van a mélyponton, amit a hazai és nemzetközi vírushelyzet alakulása is alátámasztani látszott. Azt azonban senki sem várta, hogy júniusban már ilyen magas ütemben fog növekedni a tranzakcióforgalom. A havi növekedésből a bázishónaphoz képest jelentkező 2 munkanapnyi többlet 3-5\% közötti forgalomnövekedést eredményezhetett. Az ezzel korrigált, nagyjából bázisszintű júniusi forgalom azonban még mindig a második negyedév legerősebb havi teljesítményének számít. Ezt a kiugró növekedést az egyedi $(+8,2 \%)$, azon belül is az üzleti jellegü egyedi tranzakciók $(+11,5 \%)$ fütötték. Ez a jelenség a gazdaság teljesítményének alakulása tekintetében biztató, jóllehet az elszámolt tranzakcióérték továbbra is csökkenést mutat az egyedi tranzakciók esetén is $(-3,2 \%)$, ami a gazdaság további visszaesését jelzi előre, egybevágva a különböző elemzői prognózisokkal. Mindenesetre a pénzforgalmi adatokból arra lehet következtetni, hogy a korlátozások májusi feloldásával a magyar gazdaság teljesítménye emelkedésnek indulhatott.

Az egyedi tranzakciókon belül az adójellegű tételek forgalma továbbra is jelentősen csökkent $(-7,3 \%)$ az adófizetési moratórium következtében, arányát tekintve azonban csak mérsékelni tudta az üzleti jellegű tételek erőteljes növekedését.

\subsubsection{Csoportos tételek alakulása}

A csoportos beszedések forgalma márciusban (január-februári csökkenést követően) kis mértékben (1,7\%) nőtt. Ezt követően áprilisban és májusban szignifikáns csökkenést $(-9,7 \%$ és $-9,6 \%)$ tapasztaltunk. Ennek hátterében azonban nem az üzleti környezet romlása állt. A jelenség oka, hogy a csoportos beszedéseken belül a hiteltörlesztési moratórium a finanszírozás jellegű tételek számának nagyfokú 
visszaesését (-27,5\% és -25,3\%) eredményezte a közüzemi és biztosítási szektor stagnálása, illetve kismértékű emelkedése mellett.

Júniusban a csoportos beszedésen belül a közüzemi tételek az üzleti jellegü egyedi tételekéhez hasonló növekedést mutattak (11,0\%), a finanszírozási tételek forgalma pedig - a hiteltörlesztési moratórium következtében - továbbra is meredeken csökkent $(-20,9 \%)$, míg a biztosítási tételek forgalma stagnált (+o,4\%).

A csoportos átutalás két meghatározó eleménél márciusban a SZÉP kártya táplálta a bővülést. A SZÉP kártyaforgalom növekedése szoros összefüggésben áll a kormány azon döntésével, mely eltörölte a SZÉP kártya szociális hozzájárulási adóját első körben június 30-ig, majd egy május 22-i kormányrendelet alapján 2020 végéig (140/2020. és 225/2020. Korm. rendeletek).

A közvetlen csoportos átutalások növekedését ebben a hónapban a forgalom bő 1/3-át kitevő nyugdíjak 2,2\%-os bővülése fütötte. A csoportos átutalások másik összetevőjét jelentő, közvetett csoportos átutalás esetében a március stagnáláshoz döntően hozzájárult, hogy a forgalma 60,0\%-át kitevő munkabérek forgalma is stagnált (o,6\%). A foglalkoztatottság bázisidőszaki magas szintjét figyelembe véve, a o,6\%-os bővülés ugyan kedvező adatnak volt tekinthető, de ez a növekedés csak a munkabérek időben későbbi pénzügyi teljesítésének volt köszönhető. A jövedelmek kifizetése jellemzően a tárgyhónapot követően történik, így a pénzforgalmi adatok csak egy hónapos csúszással képesek egy gyorsan változó munkaerőpiaci helyzetről visszacsatolást nyújtani. A március havi kedvezőtlen foglalkoztatottsági hírek éppen ezért még nem tükröződtek egyértelmüen a márciusi átutalásforgalomban, de a munkaügyi adatok alapján ekkor már nem a későbbi visszaesés ténye, sokkal inkább annak várható mértéke volt kérdéses.

Áprilisban a csoportos átutalásoknál már kisebb mértékü csökkenés $(-2,4 \%)$ volt megfigyelhető. A közvetett csoportos átutalás fontos üzleti marker, ezért a tranzakciótípusnál mért, jelentős áprilisi visszaesés $(-8,5 \%)$ is jól mutatta a hazai gazdaság hirtelen megrendülését. Minden főbb jogcímen megtorpanás volt tapasztalható: munkabér $-5,5 \%$, ellátások $-18,4 \%$, SZÉP kártya -9,2\%. A közvetlen csoportos átutaláson belül $(+1,2 \%)$ a munkabér szintén jelentősen csökkent $(-6,1 \%)$, a tranzakciótípust az arányaiban meghatározó és a válsággal szemben ellenálló nyugdíj $(+2,1 \%)$ tartotta bázisszinten.

A csoportos átutalások forgalmának májusi csökkenése már egyértelműen a foglalkoztatottság szintjében beálló esés következménye. A két legnagyobb csökkenés a munkabér $(-11,2 \%)$ és a munkabér jellegű ellátások $(-18,1 \%)$ jogcímeken mutatkozott, növekedni egyedül a nyugdíj forgalma volt képes $(+2,1 \%)$.

Júniusban a csoportos átutalás $(+2,1 \%)$, azon belül a közvetlen csoportos átutalás $(+7,7 \%)$ forgalma ugyan szintén kiemelkedő volt, ennek hátterében azonban a nem nevesített egyéb (+43,1\%), illetve a SZÉP kártya (+135,7\%) forgalmak kiugró növe- 
kedése áll. Az üzleti jellegü közvetett csoportos átutalás adatai (-6,7\%) még nem támasztják alá a gazdasági növekedés esetleges megugrását, illetve jól mutatják a foglalkoztatottsági szint további csökkenését. A forgalom visszaesését a munkabér $(-8,1 \%)$, a munkabér jellegű ellátások $(-21,5 \%)$ és a SZÉP kártya forgalma $(-9,1 \%)$ okozzák. Utóbbi adat arra enged következtetni, hogy a versenyszektorban a SZÉP kártya szociális hozzájárulási adómentessége egyelőre kisebb mértékben képes támogatni a hazai turizmus fellendítését. A munkabérutalások számának csökkenésével szemben az elszámolt érték visszaesése némileg enyhébb (munkabér $-3,7 \%$, munkabér jellegü ellátások -9,1\%), ami az átlagkeresetek növekedését támasztja alá. A csoportos átutalások forgalmát összességében egy erőteljes negatív üzleti (közvetett csoportos átutalás) és egy legalább ilyen erőteljes pozitív nem üzleti (közvetlen csoportos átutalás) hatás befolyásolta júniusban, ami együttesen egy nem is annyira lebecsülendő forgalomnövekedésbe torkollott.

\subsubsection{Postai elszámolások}

A PEK forgalma a korábbi hónapok 8-10\%-os csökkenésével szemben júniusban stagnált $(-0,1 \%)$, ami a munkanélküli járadék $(+69,4 \%)$, a foglalkoztatást helyettesítő támogatások (+53,5\%) növekedése, illetve az ellátások (-44,5\%) és az egyéb jogcímek forgalmának (-9,5\%) csökkenése mellett állt elő. A PEK-tételek forgalma is jól tükrözi a válság következtében kialakuló munkaerőpiaci helyzetet, hiszen a különféle munkavállalói támogatások száma és aránya a bér jellegü ellátások terhére jelentősen megemelkedett a vizsgált időszakban a tranzakciótípuson belül.

\subsection{Azonnali fizetés}

2020. március 2-án oo:0o perckor sikeresen, fennakadás nélkül elindult Magyarországon az azonnali fizetési rendszer. A GIRO Zrt. által üzemeltetett központi elszámolómű az indulás óta üzemszerüen működik. A hosszú és eredményes tesztidőszakot követően a központi infrastruktúra és a banki alkalmazások egyaránt jól vizsgáztak, a rendszer minden résztvevője sikeresen vette az első akadályokat.

\subsubsection{Mennyi idő az „azonnal”?}

$\mathrm{Az}$ azonnali rendszerbe való bekerülés feltételeinek megfelelő átutalások elméletileg 5 másodperc alatt teljesülnek. Az első 4 hónap adatai azt mutatják, hogy ez a gyakorlatban is megvalósul (1. ábra). 


\section{1. ábra}

\section{Az azonnali átutalás tranzakciók feldolgozási ideje (2020. március-június)}

\section{Teljes feldolgozási idő}

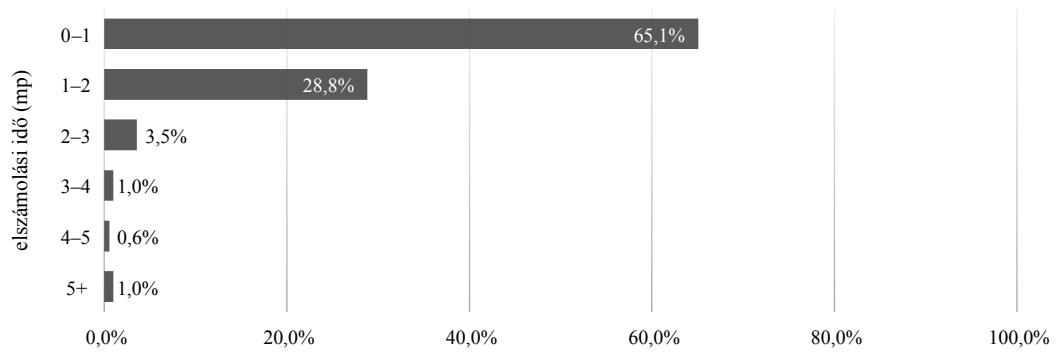

elszámolt átutalások száma (\%)

GIRO feldolgozási idő

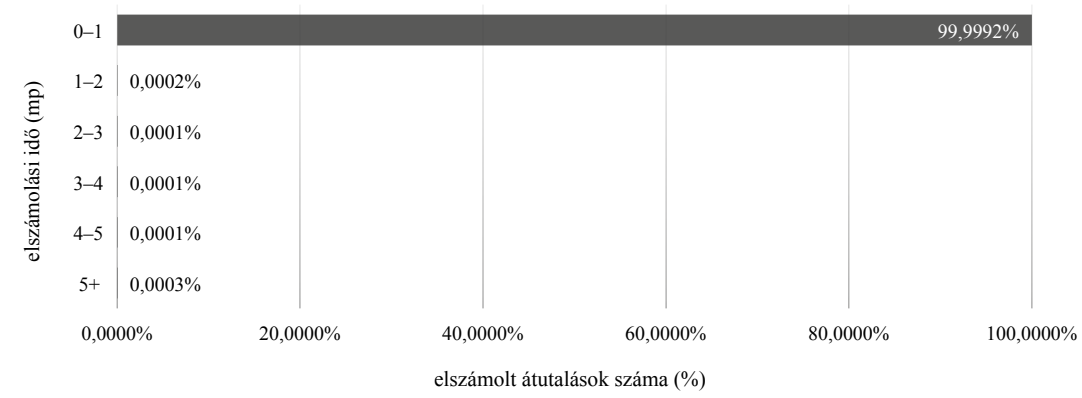

Forrás: saját szerkesztés a GIRO Zrt. adatai alapján

Az azonnali fizetés központi infrastruktúrájának teljesítménye a várakozásoknak megfelelő, az elszámolóháznál szinte minden tranzakció 1,6 másodpercnél ${ }^{3}$ rövidebb idő alatt került feldolgozásra (99,9992\%). Az elszámolásforgalmi rendszer egészére számított teljes teljesítési idő szintén kedvezően alakult, az átutalások 99\%-a 5 másodpercen belül, 93,9\%-uk pedig 2 másodpercen belül jóváírásra került a fogadó bank számláján. Az azonnali fizetést kiszolgáló informatikai rendszerek tehát még a legforgalmasabb időszakokban is az elvárt módon végezték feladatukat.

3 A GIRO Zrt. által a Bankközi Klíring Rendszer Üzletszabályzatában vállalt határidő a GIROInstant platformba a szabványnak megfelelően beérkezett, azonnali átutalási tranzakciók 95 százalékának elszámolására. 


\subsubsection{Az azonnali fizetés kezdeti időszakának jellemzői}

Június végéig az éles indulástól számítva 35,8 millió tranzakció került elszámolásra az azonnali fizetési rendszerben 5,115 milliárd Ft értékben. Az egyes hónapok értékeit a 2. táblázatban foglaltuk össze.

\section{2. táblázat}

Az azonnali fizetési rendszer átutalásainak havi számai és értékei

\begin{tabular}{lrrrr}
\hline & 2020. március & 2020. április & 2020. május & \multicolumn{1}{c}{ 2020. június } \\
\hline volumen $(\mathrm{db})$ & 9323871 & 9018830 & 8882098 & 8584442 \\
érték $(\mathrm{Ft})$ & 1363672405222 & 1248190394991 & 1226780242238 & 1276562297843 \\
\hline
\end{tabular}

Forrás: penzforgalom.hu; GIRO Zrt.

A pandémiás helyzetben az azonnali fizetés a legbiztonságosabb fizetési mód. A rendszer indulásakor a szakértők vélekedése az volt, hogy ennek felismerése és gyakorlati elterjedése csökkentheti a gazdaság várható lassulásából eredő tranzakcióforgalom-csökkenést.

A várakozásoknak megfelelően a koronavírus elleni védekezés az azonnali fizetési rendszer müködésére is rányomta bélyegét. A 4 hónap során a tranzakciószámok hónapról hónapra csökkentek, míg a tranzakcióérték két hónap csökkenés után júniusban már emelkedést mutatott.

A Bankközi Klíring Rendszer a legnagyobb visszaesést $(-6,4 \%)$ áprilisról májusra mutatta, ekkor azonban az azonnali átutalások számának csökkenése csupán 1,5\% volt. Ugyanekkor az InterGIRO2 platformon elszámolt egyszerü átutalások csökkenése 5,2\% volt, ami vélhetően a koronavírus miatti gazdasági lassulás okozta kötegelt vállalati átutalásszám visszaesésével indokolható.

Az új GIROInstant platform részaránya a teljes forgalomban kezdetben valamivel 50\% felett alakult. Júniusban a GIROInstant forgalma csökkent, az InterGIRO2 platform forgalma pedig jelentősen nőtt $(8,7 \%)$, az új platform részaránya ennek megfelelően némileg csökkent (47,8\%-ra). Az átáramlás ütemének ugrásszerü növekedése a kötegelt fizetési megbízásoknak az azonnali fizetési rendszerben történő elszámolásától várható szeptember 1-jétől. További lökést adhat az azonnali fizetésnek az online pénztárgépek melletti elektronikus fizetés kötelező lehetővé tétele (2021 elejétől).

Az azonnali fizetésre vonatkozó szabály értelmében a 10 millió forint alatti utalásokat kell kötelezően az új platformon keresztül elszámolni, ugyanakkor a vizsgált időszakban ezt meghaladó, egyedi tételeket is forgalmaztak a klíringtagok az azonnali infrastruktúrában. Ez azonban érdemben nem befolyásolja az összesen volumen- és értékadatokat - ugyan több száz millió Ft értékű tranzakciók is elöfordultak, de összességében is csak néhány darabról beszélhetünk. Megállapít- 
ható, hogy a kisösszegü tranzakciók dominálnak a rendszerben, az induláskor (március hónapban) a 10 ezer Ft egyedi érték alatti tranzakciók aránya 37\% volt, a teljes forgalom 97\%-ánál pedig 1 millió Ft alatti volt a tranzakcióérték.

$\mathrm{Az}$ az azonnali fizetés térnyerése a kiegészítő szolgáltatások terén egyelőre mérsékelt ütemü. A másodlagos számlaazonosítók, illetve a fizetési kérelmek használata még sporadikus - az e-mail címre, mobiltelefonszámra, adószámra vagy adóazonosítóra indított azonnali átutalások aránya júniusban $0,04 \%$ volt, míg a fizetési kérelem alapján teljesült tranzakciók aránya a o,01 \%-ot sem érte el. Ez természetesen abból is adódik, hogy az átutalások esetén az új platform használata kötelező, a kiegészítő szolgáltatásoké pedig nem. Ebből fakadóan utóbbiak esetén jóval lassabb felfutásra lehet számítani.

Az azonnali átutalások időbeli eloszlását a 2. ábra szemlélteti. Az ábra 168 óra átlagos tranzakció volumen- és értékadatait mutatja be úgy, hogy a munkaszüneti napokat (márc. 15., máj. 1., húsvét, pünkösd) kiszürtük. Az adatvizualizáció tehát az azonnali fizetési rendszer egy átlagos hetét és annak napjait reprezentálja.

A tranzakciók napon belüli eloszlása sok hasonlóságot mutat az InterGIRO2-vel, alapvetően munkaidőben csúcsosodik a forgalom. Az éjszakai/hajnali órákban minimális tranzakciószámot (néhány száz tranzakció óránként) figyelhetünk meg, reggel 5 és 8 óra között van egy intenzív, a lineárisnál meredekebb növekedés, ami átlagosan 10-11 óra között csúcsosodik (közel 40 ezer tranzakció/óra). A környező óráknál egyértelműen alacsonyabb 12-13 óra közötti értékek az ebédidőt jelzik. A tranzakciószám ezt követően némileg visszaesik a délutáni órákra, amikor 28-33 ezer körül szór a forgalom. Délután 4 óra után meredeken csökken, majd este 9 órától fokozatosan esik vissza közel nullára.

Az átutalások heti eloszlására jellemző, hogy - nem meglepő módon - hét végén jelentősen alacsonyabb forgalom tapasztalható. A hétvégi forgalom az átutalások számát tekintve 27,6\%-a, értékét tekintve pedig 12,1\%-a a hétköznapinak.

A hét első felének napjai (hétfő-csütörtök) nagyon hasonló képet mutatnak - a szerdai és a csütörtöki nap szinte teljesen egyforma, míg a hétföt és a keddet minimálisan intenzívebb forgalom jellemzi. Pénteken délután hamarabb és meredekebben kezdenek visszaesni a tranzakciószámok a sok esetben rövidebb munkaidőből és a közelgő hétvégéből fakadóan.

Szombaton alacsonyabb, viszonylag egyenletes átutalásszámot tapasztalhatunk a hétköznapokhoz hasonlóan 10-11 óra közötti csúccsal. Az azonnali fizetés bevezetésének adatelemzési szempontból az egyik legérdekesebb hozadéka a vasárnapi nap. A forgalom itt meglepően magas (34\%-kal magasabb, mint szombaton), és a többi nappal szemben (egy 10 és 12 óra közötti, szintén magas érték mellett) este 19 és 21 óra között csúcsosodik óránkénti kb. 10 ezer tranzakciós forgalommal, amiből a következő hetet megelőző, egyfajta előrehozott munkavégzésre következtethetünk. 


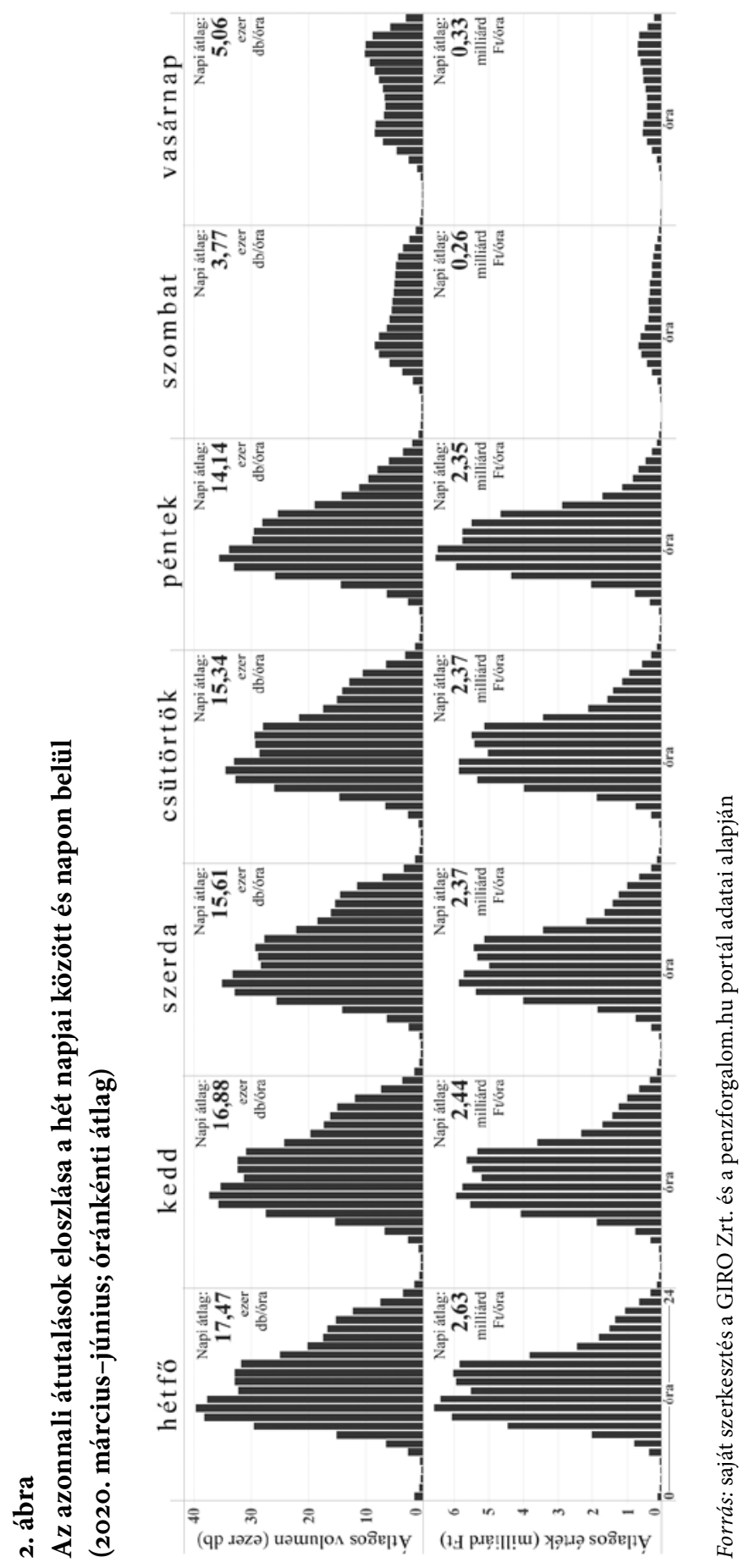




\section{ÖSSZEFOGLALÁS}

Az azonnali fizetési rendszer indulása egybeesett a koronavírus-járvány következtében meghozott szigorító intézkedések bevezetésével. A pandémia és az általa kiváltott, megváltozott körülményrendszer megnehezíti az azonnali fizetés elterjedését, annak monitorozását; ugyanakkor a klíringrendszer adatainak felhasználásával kiváló lehetőséget biztosít a jelen speciális gazdasági helyzet hatásainak vizsgálatára.

Egy pénzforgalmi innováció elterjedésének vizsgálatakor sem tekinthetünk el az általános gazdasági környezettől, ebben az esetben azonban különösen fontos a klíringrendszer számai és a gazdasági események, illetve szabályozások közötti összefüggések feltárása.

A koronavírus hatása a BKR és az azonnali átutalások márciusi forgalmát érdemben még nem tudta befolyásolni; a továbbiakban azonban jelentős visszaesés volt tapasztalható a gazdaság általános lassulása mellett. Az egyedi, illetve a munkahelyek tömeges megszünése miatt a csoportos átutalások, a törlesztési moratóriumon és a szűkülő biztosítási piacok következtében pedig a csoportos beszedések terén egyaránt csökkent a forgalom. Június hónapban már pozitív tendenciák is mutatkoztak.

Az azonnali fizetési rendszer forgalmára hatást gyakorolt a vírushelyzet, de maga az infrastruktúra jól vizsgázott. A rendszer zökkenőmentes bevezetését követően stabilan müködik. Az elkövetkezendő időszak forgalmát alapvetően az fogja meghatározni, hogy milyen lesz a fertőzés lefutása, és hogyan sikerül a történelmi léptékü állami gazdaságvédelmi intézkedésekkel ennek hatását tompítani. Az azonnali fizetés valódi térhódítása a járvány elleni védekezés gazdaságot korlátozó időszaka után kezdődhet meg igazán.

Azt mindenesetre kijelenthetjük, hogy a továbbiakban is érdemes lesz a magyar gazdaság teljesítményét és a klíringrendszer müködését összefüggéseiben elemezni. 


\section{HIVATKOZÁSOK}

Baldwin, R. - Weder di Mauro, B. (2020): Economics in the Time of COVID-19. CEPR Press Centre for Economic Policy Research, London, p. 115, ISBN: 978-1-912179-28-2.

DÁvid SÁndor - KovÁcs Levente (2019): Az elszámolásforgalom fejlődése - paradigmaváltás. Gazdaság és Pénzügy 6(3), 284-298.

GIRO Zrt. (2020): Bankközi Klíring Rendszer Üzletszabályzata, hatályos 2020. márc. 2-től, elfogadva: 1/2020/1. számú igazgatósági határozat (https:/www.giro.hu/szolgaltatasok/bankkozikliring-rendszer\#).

Kovács Levente - Divéki Éva - DÁvid Sándor - PÁl Zsolt - KAdA Zsolt (2016): A kis értékü pénzforgalom és elszámolási rendszerei. Miskolc: Miskolci Egyetemi Kiadó.

Kovács Levente (2017): Pénzügyi szektor a bizalmatlanság markában. In: Kovács Levente - Sipos JózSEF (2017): Ciklusváltó évek, párhuzamos életrajzok. Budapest: Magyar Bankszövetség - Semmelweis Kiadó, 9-26, http://bankszovetseg.hu/Public/publikacio/Ciklusv\%C3\%A1lt\%C3\%B3\%20 \%C3\%A9vek\%2C\%2op\%C3\%Arrhuzamos\%20\%C3\%A9letrajzok.pdf.

MNB (2020a): Fizetés Rendszer Jelentés. Budapest, 2020. július, ISSN 2498-7077.

MNB (2020b): Pénzügyi Stabilitási Jelentés. Budapest, 2020. május, ISSN 2064-941X.

VÁradi A. - Ferenci T. - Falus A. (2020): A koronavírus okozta COVID-19-pandémia. Orvosi Hetilap 161(17), 644-651.

Kormányrendeletek

140/2020. (IV. 21.) Korm. rendelet - A Gazdaságvédelmi Akcióterv keretében a koronavírus-járvány gazdasági hatásainak mérséklése érdekében szükséges adózási könnyítésekről

225/2020. (V. 22.) Korm. rendelet - A Gazdaságvédelmi Akcióterv keretében a koronavírus-járvány gazdasági hatásainak mérséklése érdekében szükséges adózási könnyítésekről szóló 140/2020. (IV. 21.) Korm. rendelet módosításáról

\section{Honlapok}

A magyar kormány tájékoztató oldala a koronavírusról: https://koronavirus.gov.hu/.

Egészségügyi Világszervezet (WHO) honlapja:

https://www.euro.who.int/en/health-topics/health-emergencies/coronavirus-covid-19.

Európai Betegségmegelőzési és Járványvédelmi Központ (ECDC) honlapja: https://www.ecdc. europa.eu/en/coronavirus.

Gazdaságvédelmi Akcióterv - Magyarország Kormányának honlapja: https://www.kormany.hu/hu/ hirek/a-gazdasagvedelmi-akcioterv-fobb-pontjai.

\section{Adatforrások}

A Bankközi Klíring Rendszer adatai - GIRO Zrt.; www.penzforgalom.hu.

A Központi Hitelinformációs Rendszer adatai - GIRO Zrt.; BISZ Zrt.

MNB: Elszámolásforgalmi rendszerek nyitvatartási naptára, 2019-2020, https://bit.ly/33X33Ip. 